The Chittagong Univ. J. B. Sci.,Vol. 4(1 \&2):91-98, 2009.

\title{
CHARACTERIZATION OF PROTEASE PRODUCING FUNGI ASPERGILLUS FUNICULOSUS AND A. TAMARII, AND THEIR PROTEASES.
}

\author{
Z. SHAHINA, M. T. HOSSAIN AND M. A. HAKIM ${ }^{1}$ \\ Department of Microbiology, University of Chittagong, Chittagong-4331, Bangladesh.
}

\begin{abstract}
Two Aspergillus spp. namely A. funiculosus $\left(\mathrm{Z}_{\mathrm{a}}\right)$ and A tamarii $\left(\mathrm{Z}_{\mathrm{c}}\right)$ were isolated, purified, identified and studied for their protease activity under some selected environmental condition and nutritional factors. The strains showed the maximal activity of protease after 5 days $\left(Z_{a}\right)$ and 6 days $\left(Z_{c}\right)$ of incubation at $27^{\circ} \mathrm{C}$ in a medium containing peptone as nitrogen source with $\mathrm{pH}$ 5.0. Isolate $\mathrm{Z}_{\mathrm{a}}$ showed highest protease activity in the presence of fructose as carbon source, at $35{ }^{0} \mathrm{C}$, with $\mathrm{pH} 6.0$ and $2.5 \%$ casien as substrate concentration. Where as for $\mathrm{Z}_{\mathrm{c}}$ it was starch as carbon source, temperature $40{ }^{0} \mathrm{C}$, with $\mathrm{pH} 7.0$ and $2 \%$ casien ,the isolate showed highest enzyme activity.
\end{abstract}

Key words: Aspergillus funiculosus, Aspergillus tamarii, Protease.

\section{INTRODUCTION}

Proteases are complex group of enzymes collectively known as peptidylpeptide hydrolase. These may include proteinases and peptidases that hydrolyze the peptide bonds in protein molecules. Microbial proteases have to a certain extent replaced the traditional proteases from animal and plant origin and in addition, have found further applications due to their special properties and types namely acid, neutral and alkaline(Dilip et.al. 2004).A number of fungi produce proteases in an appreciable good yield Thus the large scale production of fungal proteases has legitimately made use of a large cross section of fungal species; such as Mucor delemar, Aspergillus flavus, Aspergillus oryzae, Aspergillus awenti Aspergillus funiculosus, Aspergillus tamarii, Amylomyces rouxi Proteases account for a major share of global enzyme market. They have been used for the production of value-added products in diverse fields in various industries such as Detergent industry, Food and Dairy industry, Lather industry, Medical industry etc. Proteases are also known for their catalytic use in synthetic chemistry.It can solubilize proteinaceous wastes and so lower the BOD of waste systems. For the

${ }^{1}$ Corresponding author 
SHAHINA ET AL.

above concern the present study was conducted for the isolation, identification and characterization of protease producing fungi and their proteases.

\section{MATERIALS AND METHODS}

\section{Microorganisms}

The isolates Aspergillus funiculosus and A tamarii were isolated,purified and identified from spoiled pulse seeds.

\section{Isolation and screening of the isolates}

For the isolation of proteolytic microorganisms enrichment technique was followed. Primary screening was done by three methods - Egg albumin degradation, Skimmed milk casein hydrolysis and Gelatin hydrolysis. After primary selection, the isolates were examined for the protease activity in liquid medium.

\section{Measurement of Enzyme Activity}

Protease activity was determined by the modified method of Hayashi et.al. (1967), as followed by Meyers and Ahearn(1977).Three ml of culture filtrates, 3ml of citrate phosphate buffer and $3 \mathrm{ml}$ of $1 \%$ casein were mixed and incubated at $35^{\circ} \mathrm{C}$ in a water bath. After reaction, $5 \mathrm{ml}$ of $20 \%$ TCA was added with the solution to stop the reaction. After one hour, the solution was filtered by Whatman no. 40 (Ashless). One ml enzyme substrate mixture was taken into a test tube and $2 \mathrm{ml}$ of $20 \% \mathrm{Na}_{2} \mathrm{CO}_{3}$ and $1 \mathrm{ml}$ of Folin Ciocalteu Reagent was added and mixed well. Six ml distilled water was added to it and after 30 minutes absorbance of the solution was measured at $650 \mathrm{~nm}$ in a spectrophotometer and calculated the amount of amino acids released from a standard curve plotted from known concentration of tyrosine. Enzyme activity was expressed in Unit, which was defined as the amount of enzyme that releases $1 \mu \mathrm{g}$ of tyrosine $/ \mathrm{ml}$ of crude extract /hour.

\section{Biomass Yield}

Biomass was determined by dry weight method.

\section{Optimization of Culture Conditions}

A. Effect of incubation time, temperature and medium $\mathrm{pH}$

To observe the effect of culture conditions the organism were studied at different incubation time (3, 4,5,6 and 7 days), at different $\mathrm{pH}$ (5.0, 6.0, 7.0, 8.0 and 9.0) and temperature $\left(30 \pm 2^{\circ} \mathrm{C}, 37 \pm 2^{\circ} \mathrm{C}\right.$, and $\left.45 \pm 2^{\circ} \mathrm{C}\right)$. Biomass characteristics, biomass yield and protease production was also recorded. 


\section{B. Effect of carbon sources}

The production of extracellular proteases using different carbon source and the original nitrogen source (peptone) was studied in the liquid culture medium (Matta et al. 1975). Five carbon sources (sucrose, dextrose, fructose, starch, and maltose) were added to the medium and their effect on the production of protease, extracellular protein and biomass yield were recorded.

\section{Factors affecting enzyme activity}

\section{Temperature and $\mathrm{pH}$}

The effect of $\mathrm{pH}$ on protease activity was determined by incubating the reaction mixture at $\mathrm{pH}$ values ranging form 5.0 to 9 using citrate phosphate buffer. Optimum temperature for enzyme activity was determined by conducting the assay at various temperatures from 35 to $45 \pm 2{ }^{0} \mathrm{C}$ during enzyme substrate reaction.

\section{Enzyme substrate reaction time}

To ascertain the effect of incubation time on enzyme activity the enzyme substrate reaction mixture were incubated for different incubation time i.e. 10, 20, $30,40,50,60,70,80$ and 90 minutes and the results were recorded.

\section{Substrate concentration}

The effect of substrate concentration was measured using different concentrations of casein (i.e. 0.5, 1.0, 1.5, 2.0, 2.5 and 3.0\%)

\section{Substrate specificity}

Four different types of natural proteins such as Casein, Egg albumin, BSA and Gelatin were used to observe the substrate specificity and enzyme activity was measured separately for each substrate.

\section{RESULTS AND DISCUSSION}

Using enrichment techniques 16 microbial isolates were isolated from spoiled pulses. These isolates were purified, preserved and tested for their proteolytic activity.

\section{Screening and identification of selected isolates}

Among the isolates the fungal isolate $\mathrm{Z}_{\mathrm{a}}$ and $\mathrm{Z}_{\mathrm{c}}$ exhibited higher proteolytic activity in broth medium and were selected for further studies. The isolates were identified on the basis of their colony color, spore size, shape, arrangement, different types of conidiophores and sporangiophores, presence or absence of other special morphological features etc. The isolates were found to 
SHAHINA ET AL.

belong to the genus Aspergillus, and closely related to the species Aspergillus funiculosus G. Smith and Aspergillus tamarii kita G. Smith while compared with the standard description given by Gilman, 1957.

\section{Optimization of Different Cultural Conditions}

\section{Effects of incubation time}

The fungal isolates showed varied degrees of protease activity at different incubation periods (Fig: 1a). The isolate $\mathrm{Z}_{\mathrm{a}}$ (Aspergillus funiculosus) showed maximum activity after 5 days of incubation period. It was also reported by Shumi et.al. (2004) and the isolate $\mathrm{Z}_{\mathrm{c}}$ (Aspergillus tamarii) showed maximum enzyme production after 6 days of incubation.

\section{Effects of temperature}

Both the isolates $Z_{a}$ and $Z_{c}$ showed maximum protease activity and highest biomass yield at $27^{\circ} \mathrm{C}(\mathrm{Fig}: 1 \mathrm{c})$.

\section{Effects of $p H$}

Maximum protease production was recorded at $\mathrm{pH} 5.0$ and 6.0 by the fungal isolates $Z_{a}$ and $Z_{c}$ respectively (Fig: $1 b$ ).

\section{Effect of carbon source}

In the present study effect of carbon source were tested by using peptone as nitrogen source. Different carbon sources such as sucrose, fructose, maltose, starch, and dextrose were used. The isolate $Z_{\mathrm{a}}$ showed maximum protease activity when fructose was uaed and isolate $Z_{c}$ showed maximum activity when starch was used as a carbon source(Fig:1d)

Different authors reported variability of carbon and nitrogen sources with different organisms (Ograydziak and Yamada 1983, Haab et.al.1990, Sabita et.al.1995, Kalisz et. al. 1986, Micales 1992, Hossain et. al. 1999 and Marzan et. al. 2002).

\section{Factors involved in enzyme activity}

Enzyme activity depends upon the $\mathrm{pH}$, temperature, incubation time, substrate concentration and many others factors. So it is necessary to find out different limiting factor for maximum activity of proteases.

The crude enzyme of fungal isolates $\mathrm{Z}_{\mathrm{a}}$ (Aspergillus funiculosus) showed highest protease activity at $40^{\circ} \mathrm{C}$ for 70 minutes incubation and 80 minutes at $40^{\circ} \mathrm{C}$ for $\mathrm{Z}_{\mathrm{c}}$ (Aspergillus tamarii) (Fig:2). The isolates were allowed to react with different substrate concentrations (0.5 to 3\%) and maximum activity was found with $2.5 \%$ for $Z_{a}$ and $2.0 \%$ for $Z_{c}$, while casein was used as 


\section{PROTEASE PRODUCING FUNGI A. FUNICULOSUS AND A. TAMARII}

substrate(Fig:3).Temperature and $\mathrm{pH}$ are also most important limiting factors, which markedly influenced enzyme activity. Maximum protease activity of crude enzyme extract of fungal isolate $\mathrm{Z}_{\mathrm{a}}$ was recorded at reaction mixture temperature $35^{\circ} \mathrm{C}$ and $\mathrm{pH}$ was 6.0 (Fig:4), where as for $\mathrm{Z}_{\mathrm{c}}$ temperature was $40^{\circ} \mathrm{C}$ and $\mathrm{pH}$ 7.0(Fig:5).Similar work at acid to neutral $\mathrm{pH}$ and different temperature was also done by Shumi et. al. 2004, and Das et. al. 2005.

Using Aspergillus spp. many researchers (Chao and Gruen.1987, Channe and Shewal.1998, Liu et.al.1998, Shumi et.al.2004 and Hossain et.al. 2006) worked to understand the nature of protease enzyme and their catalytic potentiality. From the present study, it can be said that both the species $A$ funiculosus and $A$ tamarii showed a little difference in their protease activity. Further investigation on these two species can possibly reveal their potentiality as a source of protease for any biotechnological approach.

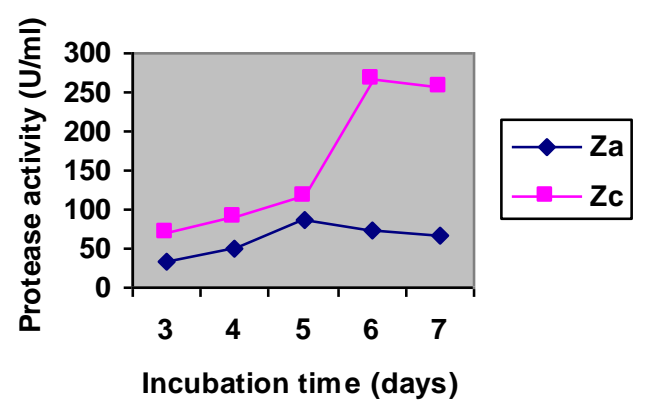

(a)

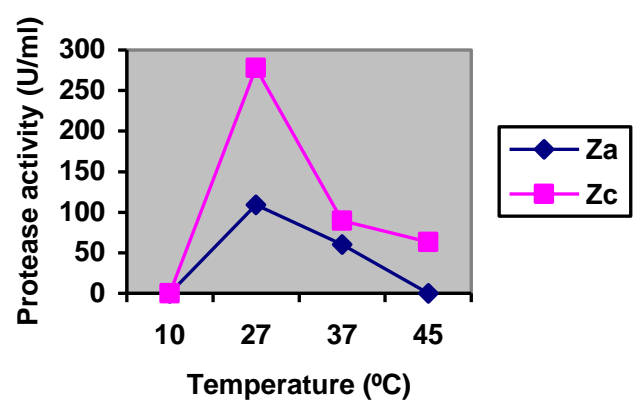

(c)

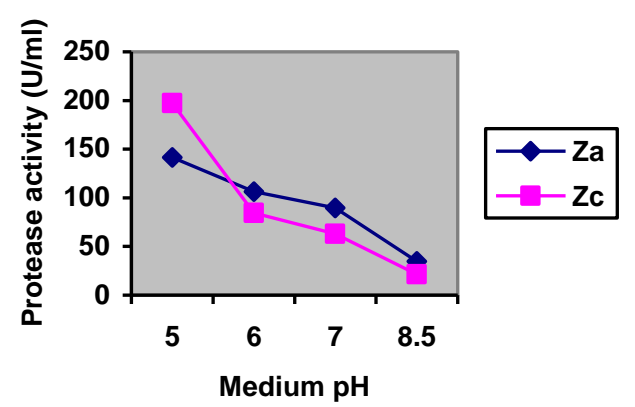

(b)

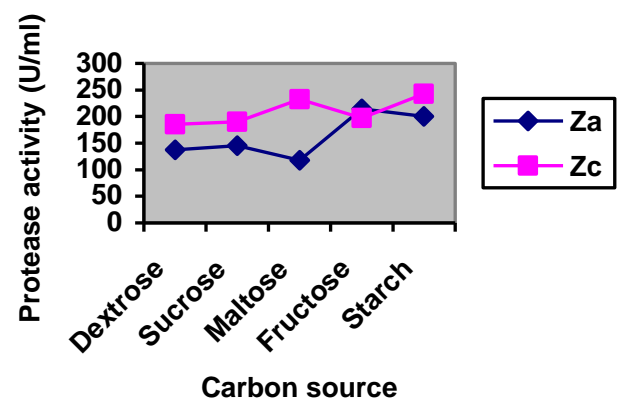

(d)

FIG.1: EFFECTS OF DIFFERENT FACTORS ON THE PRODUCTION OF PROTEASE BY A. FUNICULOSUS $\left(\mathrm{Z}_{\mathrm{A}}\right)$ AND A. TAMARI $\left(\mathrm{Z}_{\mathrm{C}}\right)$. (A) INCUBATION TIME (B) MEDIUM PH (C) INCUBATION TEMPERATURE (D) DIFFERENT CARBON SOURCES USING PEPTONE AS NITROGEN SOURCE. 


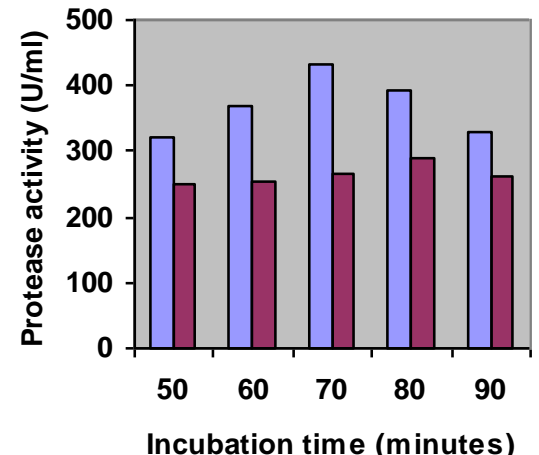

FIG.2: EFFECTS OF INCUBATION TIME ON PROTEASE (CRUDE) ACTIVITY OF THE ISOLATES A. FUNICULOSUS (ZA) AND A. TAMARI (ZC).

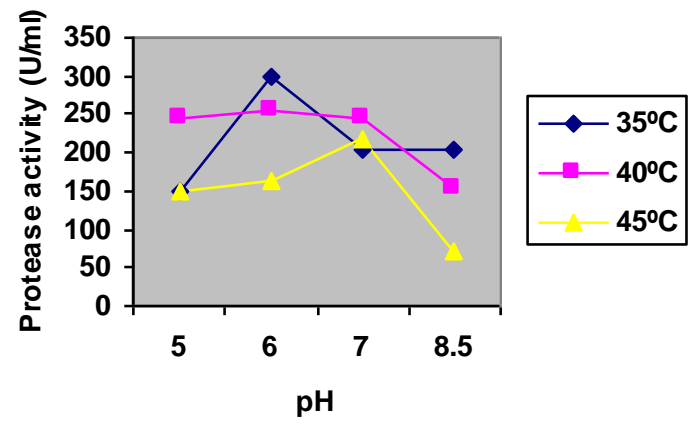

FIG.4: EFFECTS OF PH AND TEMPERATURE ON PROTEASE (CRUDE) ACTIVITY OF THE FUNGAL ISOLATE A. FUNICULOSUS $\left(\mathrm{Z}_{\mathrm{A}}\right)$.

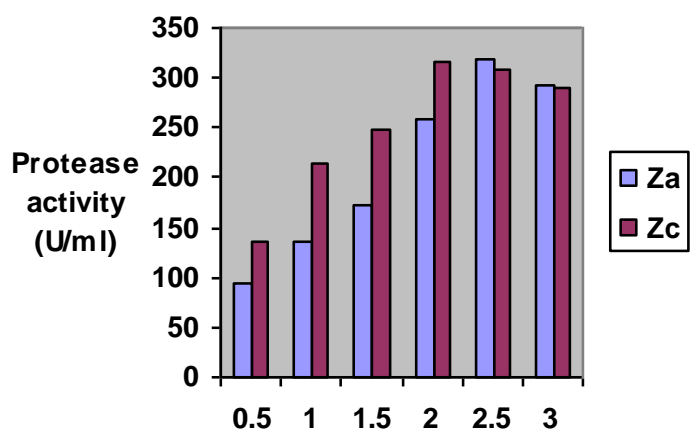

Substrate concentration (\%)

FIG.3: EFFECTS OF SUBSTRATE CONCENTRATION (\%) ON PROTEASE (CRUDE) ACTIVITY OF THE ISOLATES A. FUNICULOSUS AND A TAMARII .

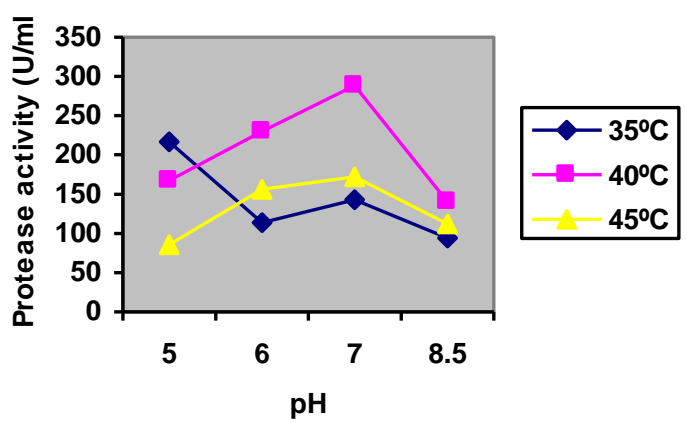

FIG.5: EFFECTS OF PH AND TEMPERATURE ON PROTEASE (CRUDE) ACTIVITY OF THE FUNGAL ISOLATE $A$. TAMARII $\left(\mathrm{Z}_{\mathrm{C}}\right)$.

\section{REFERENCES}

CHANNE, P.S. AND SHEWAL, J.G. 1998. Influence of culture conditions on the formation of milk clotting protease by Aspergillus niger MC4. World. J. Microbiol. Biotechnol. 14(1): 11-15. 
CHAO, E.E. AND GRUEN, H.E. 1987. Intracellular activity of mycelial proteinases during fruit body development in Flammulina velutipes. Canad. J. Bot. 65: 518-525.

DAS, F., HOSSAIN, MD. T. AND ANWAR, M.N.2005.Protease production by Bacillus Sphaericus. The Chittagong univ.J.Sci, 29(1):71-76.

DILIP,K.A., BRIDGE,P.D. AND BHATNAGAR, D.2004. Handbook of Fungal Biotechnology .p.p:387-388.

GILMAN,J.C.,1957.A Manual of Soil fungi (second Indian Report),Oxford and Piblishing co.New Delhi, India, pp:220 and 243.

HAAB, D., HAGSPIEL K., SZAKMARY, K. AND KUBICEK, C.P. 1990. Formation of the extra cellular proteases from Trichoderma reesei QM 9414 involved in cellulase degradation. Biotechnol.16: 187-198.

HAYASHI,L.D., FUKUSHIMA, D. AND MOGI, K.1967.Agr.Biol.chem.., Tokyo 31:1237-1241.Cited from Physiology and Parasitism.Edt. by G.P.Agarwal and K.S.Bilgrami.Today and tomorrow's printers and publishers,New Delhi,India,pp:194.

HOSSAIN, M.T., AKTER. S., RAHMAN, M.S., MANCHUR, M.A. AND ANWAR, M.N. 1999. Isolation of protease producing fungi and their protease activity. The Chittagong Univ. J. Sci. 23(2): 101-106.

HOSSAIN, M.T., DAS, F., MARZAN,L., RAHMAN, M.S., AND ANWAR, M.N.2006.Some properties of protease of the fungal strain Aspergillus flavus, International journal of agriculture and biology. 8(2):162-164.

KALISZ, H.M., MOORE, D. AND WOOD, D.A. 1986. Protein utilization by basidiomycete fungi. Trans. Brit. Mycol. Soc. 86: 519-525.

LIU, FANG, WENQING, L., DARING, R., TINGYUE, G. AND MURRAY, M. 1998. Inhibition of extracellular protease secretion by Aspergillus niger using cell immobilization. Biotechnol, Lett. 20(6): 536-542.

MATTA,H., PUNJ, V. AND KANWAR, S.S. 1975.An immuno-dot assay for detection of thermostable protease from Pseudomonus sp.AFT-36 of dairy origin.Appl.Microbiol.,25:300-302.

MARZAN, L.W., MANCHUR, M.A., HOSSAIN, M.T. AND ANWAR, M.N. 2002. Production of protease and amylase by Fusarium poae. Bangladesh J. Microbiol. 18(2):127-134.

MEYERS,S.P.AND AHEARN, D.G. 1977. Mycologia,69:649-651. Cited from Physiology and Parasitism. Edt.by G.P. Agarwal and K.S.Bilgrami.Today and tomorrow's printers and publishers, New Delhi,India,pp:195.

MICALES, J.A. 1992. Proteinases of the brown rot fungus Postia placenta. Mycologia. 84(6): 815-822. 
OGRYDZIAK, D.M. AND YAMADA, T.1983. Extracelluar acid proteases produced by Saccharomycopsis lipolytica. J. Bacteriol. 154:23-31.

SABITA, R.R., RAHMAN, M. AND CHOWDHURY, N. 1995 . Extra cellular proteolytic activity of Saccharomyces cerevisiae strain DSM 1884 Bangladesh J. Microbiol. 12(122).

SHUMI, W.,HOSSAIN, M.T. AND ANWAR,M.A. 2004. Isolation and purification of Aspergillus funiculosus G. smith and its enzyme protease .Pakistan journal of biological sciences.7(3):312-317.

Manuscript received on 15.7.09; Accepted on 9.2. 10

The Chittagong University Journal of Biological Sciences, Vol.4 ( 1 \& 2): Page No : 91-98 